\title{
Complete Degradation of Type X Collagen Requires the Combined Action of Interstitial Collagenase and Osteoclast-derived Cathepsin-B
}

\author{
Ulrike I. Sires, ${ }^{\star \star}$ Thomas M. Schmid, ${ }^{\$}$ Catherine J. Fliszar, * Zhi-Qiang Wang, "Stephen L. Gluck, " \\ and Howard G. Welgus* \\ *Dermatology and "Renal Divisions, Department of Medicine, Washington University School of Medicine at The Jewish Hospital, \\ St. Louis, Missouri 63110; ${ }^{\ddagger}$ Department of Pediatrics, St. Louis Children’s Hospital, St. Louis, Missouri 63110; \\ and ${ }^{\S}$ Department of Biochemistry, Rush Presbyterian-St. Luke’s Medical Center, Chicago, Illinois 60612
}

\begin{abstract}
We have studied the degradation of type $X$ collagen by metalloproteinases, cathepsin $B$, and osteoclast-derived lysates. We had previously shown (Welgus, H. G., C. J. Fliszar, J. L. Seltzer, T. M. Schmid, and J. J. Jeffrey. 1990. J. Biol. Chem. 265:13521-13527) that interstitial collagenase rapidly attacks the native 59-kD type $X$ molecule at two sites, rendering a final product of $32 \mathrm{kD}$. This 32-kD fragment, however, has a $T_{\mathrm{m}}$ of $43^{\circ} \mathrm{C}$ due to a very high amino acid content, and thus remains helical at physiologic core temperature. We now report that the 32-kD product resists any further attack by several matrix metalloproteinases including interstitial collagenase, 92-kD gelatinase, and matrilysin. However, this collagenase-generated fragment can be readily degraded to completion by cathepsin $B$ at $37^{\circ} \mathrm{C}$ and $\mathrm{pH}$ 4.4. Interestingly, even under acidic conditions, cathepsin $B$ cannot effectively attack the whole $59-\mathrm{kD}$ type $\mathrm{X}$ molecule at $37^{\circ} \mathrm{C}$, but only the 32-kD collagenase-generated fragment. Most importantly, the 32-kD fragment was also degraded at acid pH by cell lysates isolated from murine osteoclasts. Degradation of the 32-kD type $X$ collagen fragment by osteoclast lysates exhibited the following properties: $(a)$ cleavage occurred only at acidic pH (4.4) and not at neutral pH; (b) the cysteine proteinase inhibitors E64 and leupeptin completely blocked degradation; and (c) specific antibody to cathepsin $B$ was able to inhibit much of the lysate-derived activity. Based upon these data, we postulate that during in vivo endochondral bone formation type $X$ collagen is first degraded at neutral $\mathrm{pH}$ by interstitial collagenase secreted by resorbing cartilage-derived cells. The resulting 32-kD fragment is stable at core temperature and further degradation requires osteoclast-derived cathepsin B supplied by invading bone. (J. Clin. Invest. 1995. 95:2089-2095.) Key words: metalloproteinases • endochondral bone $\bullet$ osteoclast - cysteine proteinases $\cdot$ type $X$ collagen
\end{abstract}

\section{Introduction}

Type $\mathrm{X}$ collagen is a short chain collagen synthesized by hypertrophic chondrocytes $(1,2)$ which is transiently and develop-

Address correspondence to Ulrike I. Sires, M.D., Division of Dermatology, Jewish Hospital at Washington, University Medical Center, 216 South Kingshighway, St. Louis, MO 63110. Phone: 314-454-8290; FAX: 314-454-8293.

Received for publication 25 April 1994 and in revised form 13 December 1994.

J. Clin. Invest.

(c) The American Society for Clinical Investigation, Inc.

0021-9738/95/05/2089/07 \$2.00

Volume 95, May 1995, 2089-2095 mentally regulated at sites of endochondral ossification $(3,4)$. This collagen is a homotrimer of identical $\alpha$ chains $\left(\alpha 1[\mathrm{X}]_{3}\right)$ secreted in native form of $59,000 M_{\mathrm{r}}(5)$. The molecule contains a 14-kD COOH-terminal globular domain that is sensitive to pepsin digestion and a triple helix of $45 \mathrm{kD}(6)$.

Matrix metalloproteinases are a gene family whose physiologic function involves the degradation of extracellular matrix. We previously reported (7) that native type $X$ collagen was cleaved by two such human metalloproteinases - interstitial collagenase and $72-\mathrm{kD}$ gelatinase - at two distinct loci within the triple helix. These cleavage sites, Gly ${ }^{92}-$ Leu $^{93}$ and Gly ${ }^{420}$ $\mathrm{Ile}^{421}$, represented Gly-X bonds of Gly-Xaa-Yaa-Xaa-Yaa sequences. At $37^{\circ} \mathrm{C}$, the $32-\mathrm{kD}$ product of collagenase or $72-\mathrm{kD}$ gelatinase digestion was resistant to further cleavage by either enzyme. Indeed, the $T_{\mathrm{m}}$ of the $32-\mathrm{kD}$ degradation fragment has been shown to be $43^{\circ} \mathrm{C}$ due to a very high amino acid content, and thus, is well above physiologic core temperature (8). Therefore, while metalloproteinases derived from cartilage can initiate the degradation of type $\mathrm{X}$ collagen, a very substantial helical fragment remains after digestion which may be resistant to further proteolysis.

Lysosomal cysteine proteinases including the cathepsins may also contribute to the degradation of collagen. Cathepsins $\mathrm{B}, \mathrm{L}$, and $\mathrm{N}$ can degrade insoluble type I collagen in vitro at acidic pH (9). These enzymes cleave the nonhelical telopeptide extensions on the helical side of the intermolecular cross-links, thereby solubilizing collagen molecules. They also can cleave within a subtly compromised triple helix provided by acidic $\mathrm{pH}$ and physiologic temperature (10).

Of the cysteine proteinases, cathepsin B $\left(24,000 M_{\mathrm{r}}\right)$ is the best understood and most thoroughly studied. It is found in all cells containing lysosomes, including fibroblasts, macrophages and osteoclasts (11-13), and has been demonstrated to degrade types I, II, III, IV, V, IX, and XI collagens $(10,14-16)$ as well as laminin, fibronectin, and proteoglycans (15-18). Cathepsin B exhibits a $\mathrm{pH}$ optimum of 6.0 for most substrates; activity decreases very sharply at neutral $\mathrm{pH}$ because of irreversible inactivation of the enzyme. However, for collagen degradation by cathepsin $\mathrm{B}$, activity is optimal at $\mathrm{pH} 3.5-4.5$, most likely reflecting a combination of retained enzyme function and swelling of the collagen molecule with loosening of helical structure at acidic $\mathrm{pH}$ and physiologic temperature (10).

In the present study, we show that a combination of neutral metalloproteinase and acidic cathepsin activity is required for the complete degradation of type $X$ collagen. We demonstrate that interstitial collagenase and cathepsin B are the likely enzymes involved. Our results suggest that during endochondral bone formation, type $\mathrm{X}$ collagen is only partially degraded by matrix metalloproteinases secreted by cartilage-derived cells. The complete degradation of type $\mathrm{X}$ collagen is likely accom- 
plished by invading bone osteoclasts which function in an acidic microenvironment.

\section{Methods}

Reagents. Acrylamide was purchased from Bio-Rad (Richmond, CA) and bis-acrylamide from Eastman Kodak (Rochester, NY). Sodium dodecyl sulfate, $99 \%$ pure, was obtained from BDH Chemicals, Ltd. (Poole, England). Tris base, E-64, leupeptin, pepstatin, DTT, and APMA were obtained from Sigma Chemical Co. (St. Louis, MO). Human cathepsin B was purchased from Calbiochem Corp. (La Jolla, CA). Purified recombinant rat cathepsin B was a kind gift of Dr. John Mort (Shriner's Hospital, Montreal, Canada) $(19,20)$. IgG-purified sheep anti-human cathepsin B polyclonal antibody was purchased from ICN Immunobiologicals (Costa Mesa, CA). All other chemicals were reagent grade.

Isolation and purification of human matrix metalloproteinases. Interstitial collagenase was purified to homogeneity from the conditioned medium of phorbol ester-treated U937 cells as described previously (21, 22). 92-kD gelatinase was isolated and purified from E1A-transfected HT-1080 cells as described by Wilhelm et al. (23). Purification by sequential gelatin-Agarose and red-Sepharose chromatography resulted in $92 \mathrm{kD}$ enzyme free of associated TIMP. Matrilysin obtained by transfection of linearized PEE12 PUMP expression vector into NSO mouse myeloma cells was kindly provided by Gill Murphy (Cambridge, U. K.) (24)

Activation of enzymes and verification of full catalytic activity. Interstitial procollagenase, $92-\mathrm{kD}$ progelatinase, and promatrilysin were activated by exposure to APMA, $1 \mathrm{mM}$, at $37^{\circ} \mathrm{C}$ for $1 \mathrm{~h}$. Cathepsin $\mathrm{B}$ and the osteoclast lysates were treated with $10 \mathrm{mM}$ DTT at $37^{\circ} \mathrm{C}$ for $15 \mathrm{~min}$ before use.

Proteolytic activity of each of the metalloproteinases was established by assay against known susceptible substrates as follows: $92-\mathrm{kD}$ gelatinase and matrilysin activities were tested by measuring the solubilization of ${ }^{3} \mathrm{H}$-elastin at $37^{\circ} \mathrm{C}(25)$. Collagenase activity was determined by incubation of enzyme with native rat type I collagen at $25^{\circ} \mathrm{C}$ and quantification of catalytic rate $\left(k_{\text {cat }}\right)$ by scanning densitometry of $\mathrm{TC}^{\mathrm{A}}$ products (26). Stromelysin activity was measured using a proteoglycan bead assay (27).

Preparation of collagens. Embryonic chick type $\mathrm{X}$ collagen was obtained from medium harvested from cultures of passaged chondrocytes derived from 12-d-old chick tibiotarsus. The type X collagen was separated from other proteins and other collagen types by fractional salt precipitation performed under both neutral and acid conditions and further purified by immunoaffinity chromatography using the X-Aca monoclonal antibody (28) as described previously $(29,30)$.

To obtain the $45-\mathrm{kD}$ species, type $\mathrm{X}$ collagen was digested with pepsin $(100 \mu \mathrm{g} / \mathrm{ml})$ in $0.5 \mathrm{M}$ acetic acid for $16 \mathrm{~h}$ at $4^{\circ} \mathrm{C}$, and after raising the $\mathrm{pH}$ to 8.0 with $\mathrm{NaOH}$, the collagen was precipitated with ammonium sulfate ( $30 \%$ ). The $32-\mathrm{kD}$ product of collagenase digestion was also isolated by immunoaffinity chromatography as described above. Rat tendon type I collagen was extracted by pepsin digestion and purified as described previously (7).

Assays. Incubation of the various metalloproteinases with type $\mathrm{X}$ collagen was performed in the presence of $0.05 \mathrm{M}$ Tris, $\mathrm{pH} 7.5$, containing $0.01 \mathrm{M} \mathrm{CaCl}_{2}, 0.15 \mathrm{M} \mathrm{NaCl}$, and $0.02 \%$ Brij. Reactions involving cathepsin $\mathrm{B}$ degradation of types $\mathrm{I}$ and $\mathrm{X}$ collagens were performed in $0.05 \mathrm{M}$ sodium acetate, $\mathrm{pH} 4.4$, containing $1 \mathrm{mM}$ DTT and $0.1 \mathrm{mM}$ CHAPS. For assays designed to study cathepsin B or osteoclast lysate degradation of the $32-\mathrm{kD}$ product of interstitial collagenase digestion, the following procedure was used: $(a)$ type $\mathrm{X}$ collagen was incubated with the indicated amount of collagenase in $0.05 \mathrm{M}$ Tris, $\mathrm{pH} 7.5$, containing $0.01 \mathrm{M} \mathrm{CaCl}_{2}, 0.15 \mathrm{M} \mathrm{NaCl}$, and $0.1 \mathrm{mM} \mathrm{CHAPS} ;(b)$ the reaction mixture was then brought to $\mathrm{pH} 4.4$ with the addition of 0.05 $M$ sodium acetate ( $\mathrm{pH} 1.2$ ) and sufficient DTT was added to achieve a final concentration of $1 \mathrm{mM}$; and $(c)$ cathepsin B or osteoclast lysate was then added as described. Denaturing polyacrylamide gel electrophoresis was performed in slab gels as described (31).

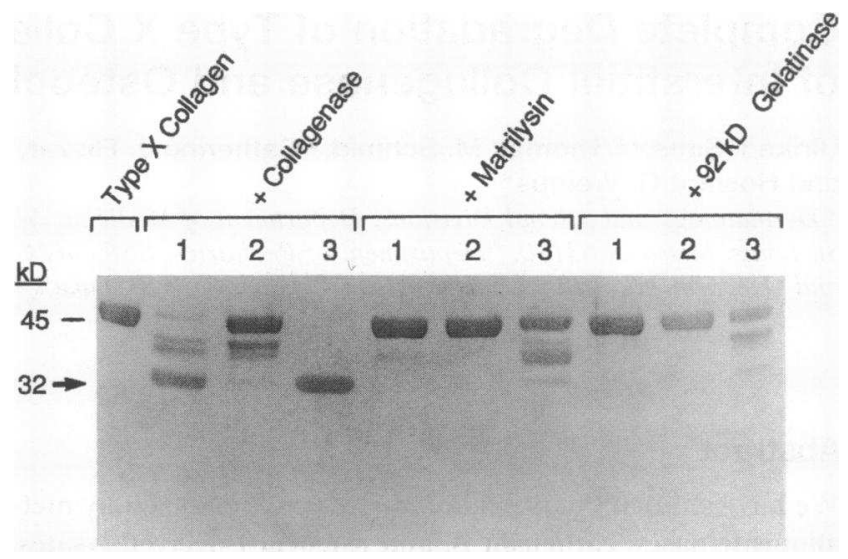

Figure 1. Capacity of various metalloproteinases to degrade native type $\mathrm{X}$ collagen. Type $\mathrm{X}$ collagen $(45 \mathrm{kD} ; 10 \mu \mathrm{g})$ was incubated at $37^{\circ} \mathrm{C}$ with the different metalloproteinases as indicated. Lanes $l$ contained $9.1 \times 10^{-7} \mathrm{M}$ enzyme and were incubated at $37^{\circ} \mathrm{C}$ for $1 \mathrm{~h}$. Lanes 2 contained $3.6 \times 10^{-7} \mathrm{M}$ enzyme and were incubated at $37^{\circ} \mathrm{C}$ for $1 \mathrm{~h}$. Lanes 3 contained $3.6 \times 10^{-7} \mathrm{M}$ enzyme and were incubated at $37^{\circ} \mathrm{C}$ for $18 \mathrm{~h}$. Reaction mixtures were stopped with SDS sample buffer containing DTT, boiled, and subjected to polyacrylamide gel electrophoresis using $8 \%$ gels. The arrow denotes formation of the $32-\mathrm{kD}$ product.

Preparation of murine osteoclast-like cells and osteoclast lysates. Osteoclast-like cells were prepared in vitro by the coculture of mouse spleen cells with PA6 stromal cells as described previously by Suda et al. (32). Cocultures were incubated for $2 \mathrm{wk}$ in the presence of both $1,25(\mathrm{OH})_{2} \mathrm{D}_{3}(10 \mathrm{nM})$ and dexamethasone $\left(10^{-8} \mathrm{M}\right)$ to promote osteoclast differentiation. To prepare cellular extracts, murine osteoclast-like cells were suspended in $20 \mathrm{mM}$ sodium acetate, $65 \mathrm{mM} \mathrm{NaCl}, 20-\mathrm{mM}$ Hepes, 1 mM EDTA, 1 mM 3-([3-cholamidopropyl]-dimethylammonio)-1-propanesulfonate (CHAPS), and were then frozen $\left(-80^{\circ} \mathrm{C}\right)$. After thawing, the cells were disrupted with a glass homogenizer and the $\mathrm{pH}$ was adjusted to 5.0. The suspension was placed on a nutator table at $4^{\circ} \mathrm{C}$ for $2 \mathrm{~h}$, subjected to ammonium sulfate precipitation (70\%), and then centrifuged at $14,000 \mathrm{~g}$ for $10 \mathrm{~min}$. The precipitate was then

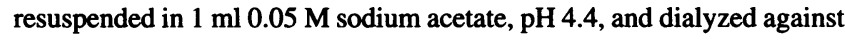
2 liters of this same buffer (33).

\section{Results}

We have previously reported that type $\mathrm{X}$ collagen is cleaved at two loci within its triple helix by human interstitial collagenase and $72-\mathrm{kD}$ gelatinase (7). In that study, it was not possible to compare the efficacy of these two matrix metalloproteinases, since the $72-\mathrm{kD}$ gelatinase was purified already in complex with its endogenous inhibitor, TIMP-2. We now use the highly related $92-\mathrm{kD}$ gelatinase, which is isolated free of associated TIMP-1 (23) to study degradation of type X collagen by metallogelatinases, and have also examined the susceptibility of this substrate to attack by matrilysin, a recently described low $M_{\mathrm{r}}$ metalloproteinase. In Fig. 1, the catalytic efficacy of human interstitial collagenase, $92-\mathrm{kD}$ gelatinase, and matrilysin against native type $\mathrm{X}$ collagen is compared using 2 different concentrations of each enzyme $\left(9.1 \times 10^{-7} \mathrm{M}\right.$ or $\left.3.6 \times 10^{-7} \mathrm{M}\right)$ incubated for either 1 or $18 \mathrm{~h}$ at $37^{\circ} \mathrm{C}$. As shown, collagenase has by far the greatest activity against type $\mathrm{X}$ collagen, although all three enzymes are capable of at least some degree of cleavage. The cleavage products resulting from catalysis by the various metalloenzymes are very similar, with the expected couplet of bands formed as intermediate degradation products ( 41 and $37 \mathrm{kD}$ ) 


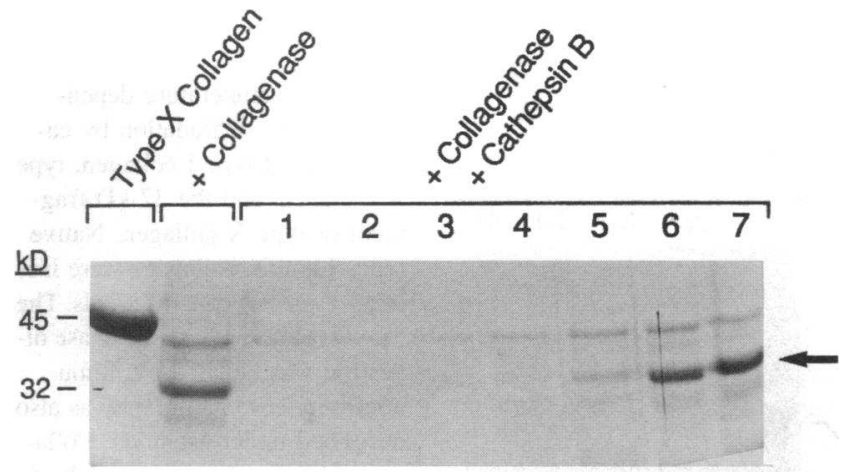

Figure 2. Capacity of cathepsin B to degrade the 32-kD fragment of collagenase digestion. Type X collagen $(45 \mathrm{kD} ; 7.5 \mu \mathrm{g})$ was incubated with collagenase $\left(1.1 \times 10^{-7} \mathrm{M}\right)$ at $37^{\circ} \mathrm{C}$ for $18 \mathrm{~h}$ in buffer containing 0.05 M Tris, 0.01 $\mathrm{M} \mathrm{CaCl}_{2}, 0.15 \mathrm{M} \mathrm{NaCl}, 0.1 \mathrm{mM}$ CHAPS, pH 7.5. After this incubation, the $\mathrm{pH}$ of the reaction mixture was lowered to

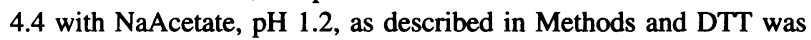
added to a final concentration of $1 \mathrm{mM}$. The reaction mixtures containing the $32-\mathrm{kD}$ fragment of collagenase digestion were then treated with the following concentrations of cathepsin $\mathrm{B}$ at $37^{\circ} \mathrm{C}$ for $24 \mathrm{~h}$ : Lane $1\left(2.6 \times 10^{-6} \mathrm{M}\right)$; lane $2\left(1.3 \times 10^{-6} \mathrm{M}\right)$; lane $3\left(6.7 \times 10^{-7} \mathrm{M}\right)$; lane $4\left(2.6 \times 10^{-7} \mathrm{M}\right)$; lane $5\left(6.7 \times 10^{-8} \mathrm{M}\right)$; lane $6\left(1.3 \times 10^{-8}\right.$ $\mathrm{M})$; and lane $7\left(1.3 \times 10^{-9} \mathrm{M}\right)$. The samples were then boiled in SDS sample buffer and subjected to polyacrylamide gel electrophoresis. The arrow denotes the $32-\mathrm{kD}$ product of collagenase digestion.

and the eventual generation of a stable $32-\mathrm{kD}$ species resulting from proteolysis at both susceptible loci (4 and $8 \mathrm{kD})$. This $32-\mathrm{kD}$ fragment resisted further degradation by any of the tested metalloproteinases, at 37 or $39^{\circ} \mathrm{C}$, even when $92-\mathrm{kD}$ gelatinase or matrilysin were added to the completely converted product so readily formed by collagenase action (not shown).

These experiments confirmed that the collagenase-generated 32-kD product of type $\mathrm{X}$ collagen retained its triple helical structure at $37^{\circ} \mathrm{C}$ (and even $39^{\circ} \mathrm{C}$, not shown), raising the question of how degradation of this collagen is completed. It has been reported previously that cathepsins such as cathepsin B can cleave helical collagens at $37^{\circ} \mathrm{C}$ and at acidic $\mathrm{pH}(10)$. This scenario seemed particularly attractive since invading bone osteoclasts have been shown to use such acidic cathepsins to degrade the primarily type I collagenous organic matrix of bone $(34,35)$.

To evaluate this possibility, type $X$ collagen was first digested to the $32-\mathrm{kD}$ fragment by interstitial collagenase at neutral $\mathrm{pH}$. The $\mathrm{pH}$ of the reaction mixture was then adjusted to 4.4 and different amounts of cathepsin $\mathrm{B}$ were added at $37^{\circ} \mathrm{C}$ for $24 \mathrm{~h}$. As shown in Fig. 2, the 32-kD fragment was completely or mostly degraded by cathepsin $\mathrm{B}$ at enzyme concentrations of $\geq 6.7 \times 10^{-8} \mathrm{M}$. Approximately $95 \%$ of the substrate was degraded by $6.7 \times 10^{-8} \mathrm{M}$ cathepsin $\mathrm{B}$ and $30 \%$ by $1.3 \times 10^{-8}$ $M$ cathepsin $B$. There were no distinct cleavage products evident from the action of cathepsin B, which apparently degraded the 32-kD collagenous domain into small peptide fragments.

Degradation of the $32-\mathrm{kD}$ fragment of type X collagen by cathepsin $\mathrm{B}$ exhibited significant temperature dependence. As

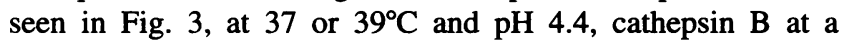
concentration of $1.3 \times 10^{-7} \mathrm{M}$ completely degraded the $32-\mathrm{kD}$ collagenase-generated fragment of type $\mathrm{X}$ collagen. However, at $35^{\circ} \mathrm{C}$, an identical concentration of enzyme degraded only $70 \%$ of the $32-\mathrm{kD}$ fragment.

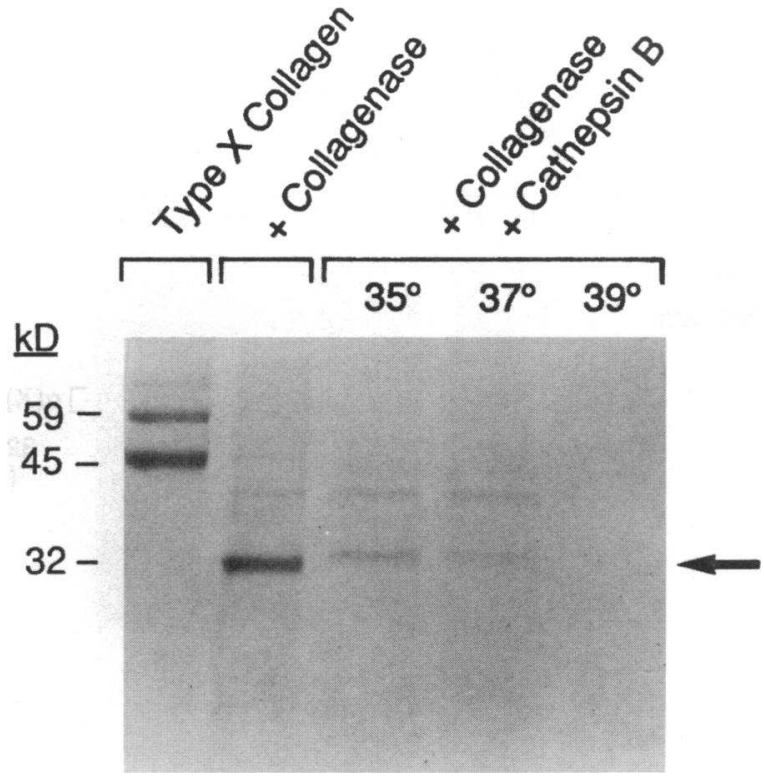

Figure 3. Temperature dependence of degradation of the 32-kD fragment by cathepsin $\mathrm{B}$. Type $\mathrm{X}$ collagen (mixture of $59,45 \mathrm{kD} ; 10 \mu \mathrm{g}$ ) was incubated with collagenase $\left(1.1 \times 10^{-7} \mathrm{M}\right)$ at $37^{\circ} \mathrm{C}$ for $18 \mathrm{~h}$ to generate the stable $32-\mathrm{kD}$ product. The reaction mixture $\mathrm{pH}$ was then lowered to 4.4 as described in Methods and cathepsin $B\left(1.3 \times 10^{-7} \mathrm{M}\right)$ added for $24 \mathrm{~h}$ at the indicated temperatures. Reaction mixture volume was $32 \mu \mathrm{l}$. The samples were then subjected to polyacrylamide gel electrophoresis. The arrow denotes the migration position of the $32-\mathrm{kD}$ product.

Since the capacity for cathepsin B to degrade native collagens at acid $\mathrm{pH}$ is related to substrate stability, we next examined this enzyme's cleavage of native whole types $I$ and $X$ collagens in comparison to the $32-\mathrm{kD}$ fragment of type $\mathrm{X}$. As seen in Fig. $4 \mathrm{~A}$, a concentration of $1.3 \times 10^{-6} \mathrm{M}$ cathepsin $\mathrm{B}$ was able to degrade only $20 \%$ of type I collagen at $35^{\circ} \mathrm{C}$, but essentially all of this substrate was cleaved at $37^{\circ} \mathrm{C}$. Fig. $4 \mathrm{~B}$ demonstrates the capacity for cathepsin B to degrade whole type $\mathrm{X}$ collagen at various incubation temperatures. At 35 and $37^{\circ} \mathrm{C}$, very little type $\mathrm{X}$ collagen was attacked, whereas at $39^{\circ} \mathrm{C}$, $>50 \%$ of the substrate was degraded. This resistance of type $\mathrm{X}$ collagen to cathepsin $\mathrm{B}$ at $37^{\circ} \mathrm{C}$ relative to type I collagen is not surprising since type $\mathrm{X}$ has a more stable helical structure due to its much higher hydroxyproline content. As shown in Fig. $4 C$, the $32-\mathrm{kD}$ fragment of type $\mathrm{X}$ collagen was much more sensitive to cathepsin $B$ digestion than was the native whole molecule. At $35^{\circ} \mathrm{C},>80 \%$ of the initial amount of 32 $\mathrm{kD}$ fragment was degraded, whereas at $37^{\circ} \mathrm{C}$, essentially all of the substrate was cleaved. These data indicate that while cathep$\sin \mathrm{B}$ cannot initiate the degradation of whole type $\mathrm{X}$ collagen at physiologic temperature, it can effectively degrade the 32$\mathrm{kD}$ fragment released by collagenase digestion.

To further evaluate the possibility that invading bone cells may complete the degradation of type $X$ collagen started by interstitial collagenase, we studied the capacity of osteoclast lysates to degrade the $32-\mathrm{kD}$ type $\mathrm{X}$ fragment. Murine osteoclasts were generated in vitro by co-culture of monocytic cells with bone stromal cells (32) and lysates prepared as described in Methods. In the experiment shown in Fig. $5 \mathrm{~A}$, type X collagen was first digested by interstitial collagenase at neutral $\mathrm{pH}$ to its $32-\mathrm{kD}$ form. The $\mathrm{pH}$ was then lowered to 4.4 and osteo- 

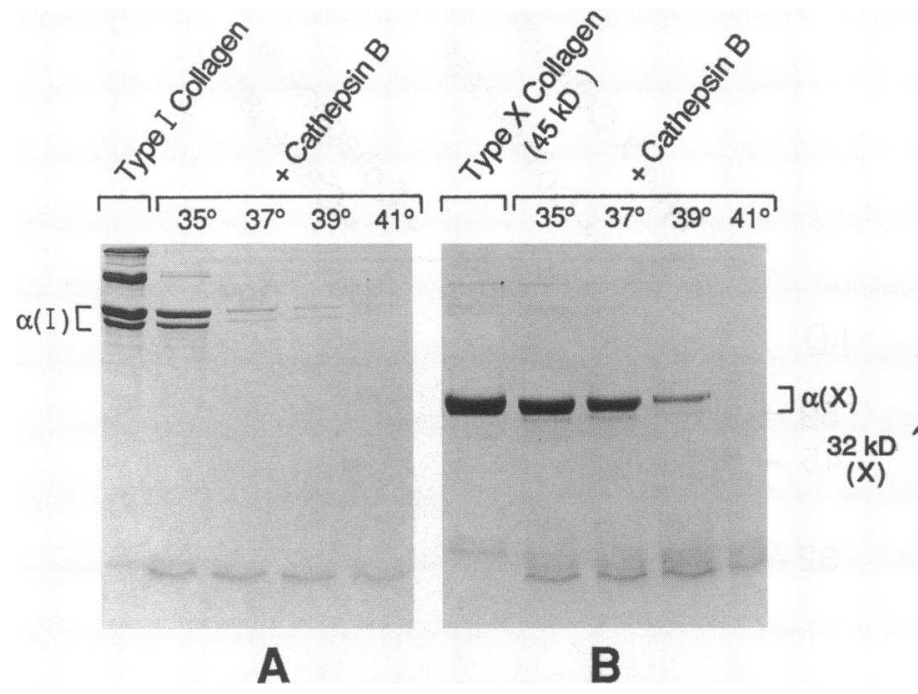

clast lysate added for $24 \mathrm{~h}$ at $37^{\circ} \mathrm{C}$. As shown in the figure, the osteoclast lysate completely degraded the $32-\mathrm{kD}$ fragment at $\mathrm{pH} \mathrm{4.4,} \mathrm{but} \mathrm{failed} \mathrm{to} \mathrm{attack} \mathrm{it} \mathrm{at} \mathrm{pH} 7.5$. Fig. $5 \mathrm{~B}$ demonstrates that complete degradation of the $32-\mathrm{kD}$ fragment occurred at $\mathrm{pH} 4.4$ at 37,39 , and $41^{\circ} \mathrm{C}$, however, no degradation occurred at pH 7.5 even at $41^{\circ} \mathrm{C}$. Next, the specific irreversible cysteine protease inhibitors, E-64 (trans-epoxy-succinyl-L-leucylamido(4-guanidino)-butane) and leupeptin were added to the osteoclast lysates at $\mathrm{pH}$ 4.4. As shown, each inhibitor completely abolished the capacity of the osteoclast lysate to degrade the 32-kD fragment (Fig. $5 \mathrm{~A}$ ). These data indicate that an acidic cathepsin in the osteoclast lysate is responsible for degradation of the 32-kD fragment. To determine whether cathepsin B is the responsible acidic cathepsin, we added specific anti-cathepsin $B$ antiserum to the osteoclast lysates. Since the polyclonal cathepsin B antibody we used was anti-human, we first established its capacity to inhibit the catalytic activity of rat cathepsin B (not shown), which is $>95 \%$ homologous to the mouse (36). As a control, the antibody preparation failed to affect the enzyme activity of human interstitial collagenase (not shown). As seen in Fig. $5 \mathrm{~A}$, the addition of cathepsin B antibody reduced the lysate's capacity to degrade the $32-\mathrm{kD}$ fragment by $\sim 50 \%$, strongly implicating this enzyme's involvement in the process.

\section{Discussion}

Our results indicate that the combined actions of a neutral metalloproteinase and an acidic cathepsin are required to completely degrade type $\mathrm{X}$ collagen. Due to a very high hydroxyproline content, whole type $\mathrm{X}$ collagen resists cleavage by cathepsin $\mathrm{B}$ at $37^{\circ} \mathrm{C}$, even in an acidic environment (Fig. 4). In contrast, several neutral metalloproteinases can catalyze the initial scissions of type $X$, with interstitial collagenase being by far the most effective (Fig. 1). However, all tested metalloproteinases, including collagenase and gelatinase, could degrade type X collagen only to a $32-\mathrm{kD}$ form, which retains its triple helical structure at physiologic temperature due to an unusually high amino acid content. Whereas the whole type $\mathrm{X}$ collagen molecule resists the action of cathepsin $\mathrm{B}$ at $37^{\circ} \mathrm{C}$, the $32-\mathrm{kD}$ fragment is readily susceptible to attack by this lysosomal cysteine

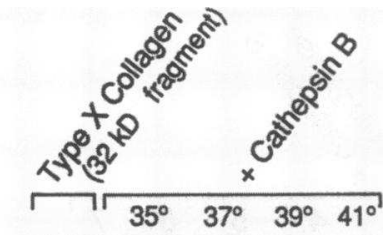

Temperature dependence of the degradation by cathepsin B of type I collagen, type $X$ collagen, and the $32-\mathrm{kD}$ fragment of type $X$ collagen. Native types $I$ and $X$ collagens were isolated as described in Methods. The 32-kD fragment of collagenase digestion was isolated by immunoaffinity chromatography as also described under Methods. Collagens ( $10 \mu \mathrm{g}$ of types I and X; 5 $\mu \mathrm{g}$ of $32-\mathrm{kD}$ fragment) were incubated with cathepsin $B$ ( 1.3 $\times 10^{-6} \mathrm{M}$ ) for $48 \mathrm{~h}$ at the indicated temperatures. Samples were then subjected to polyacrylamide gel electrophoresis. proteinase at physiologic temperature and acidic pH (Figs. 24). Thus, our data suggest that ciuring endochondral ossification, the degradation of type $\mathrm{X}$ collagen is initiated by cartilagederived cells such as chondrocytes, which secrete neutral metalloproteinases including interstitial collagenase, but is completed by the action of an acidic cathepsin, such as cathepsin B, most likely provided by osteoclasts of the invading bone.

We have previously reported (7) that degradation of type $X$ collagen can be initiated by interstitial collagenase or $72-\mathrm{kD}$ gelatinase, which at $37^{\circ} \mathrm{C}$ attack the native molecule at 2 loci, Gly $^{92}-$ Leu $^{93}$ and $\mathrm{Gly}^{420}$-Ile ${ }^{421}$, both sites representing Gly-Xaa bonds of Gly-Xaa-Yaa-Xaa-Yaa sequences. The correspondence of these susceptible sites to areas of helix imperfection explained values obtained for activation energy and deuterium isotope effect which appeared to be intermediate between those normally observed for native and denatured collagens (7). Furthermore, they provided a plausible explanation for the susceptibility of a native collagen to degradation by both an interstitial collagenase and a gelatinase. However, in this previous report we could not compare the relative efficacy of interstitial collagenase to $72-\mathrm{kD}$ gelatinase, since the latter enzyme is isolated and purified already in complex with TIMP-2, which markedly attenuates its catalytic activity. In the present study, we used the highly related $92-\mathrm{kD}$ gelatinase, which can be expressed and purified free of its endogenous inhibitor, TIMP-1 (23). As shown in Fig. 1, interstitial collagenase, 92-kD gelatinase, and matrilysin all cleaved the two susceptible loci in native type $\mathrm{X}$ collagen, eventually generating a $32-\mathrm{kD}$ fragment which was resistant to further proteolytic attack. However, interstitial collagenase was far more effective than the other two enzymes, exhibiting at least 20 -fold greater catalytic efficiency. Nonetheless, it has been reported that the $32-\mathrm{kD}$ digestion product of collagenase has a $T_{\mathrm{m}}$ of $43^{\circ} \mathrm{C}$, and therefore retains its triple helical conformation at physiologic temperature (8). Our data strongly support this finding, since the $32-\mathrm{kD}$ fragment could not be attacked by $92-\mathrm{kD}$ gelatinase, even at $39^{\circ} \mathrm{C}$, which is remarkably effective against denatured collagens of all genetic types.

The question then arose as to how complete degradation of type $\mathrm{X}$ collagen occurs. Since in the endochondral sequence, mineralized cartilage that contains type $\mathrm{X}$ as well as type II 


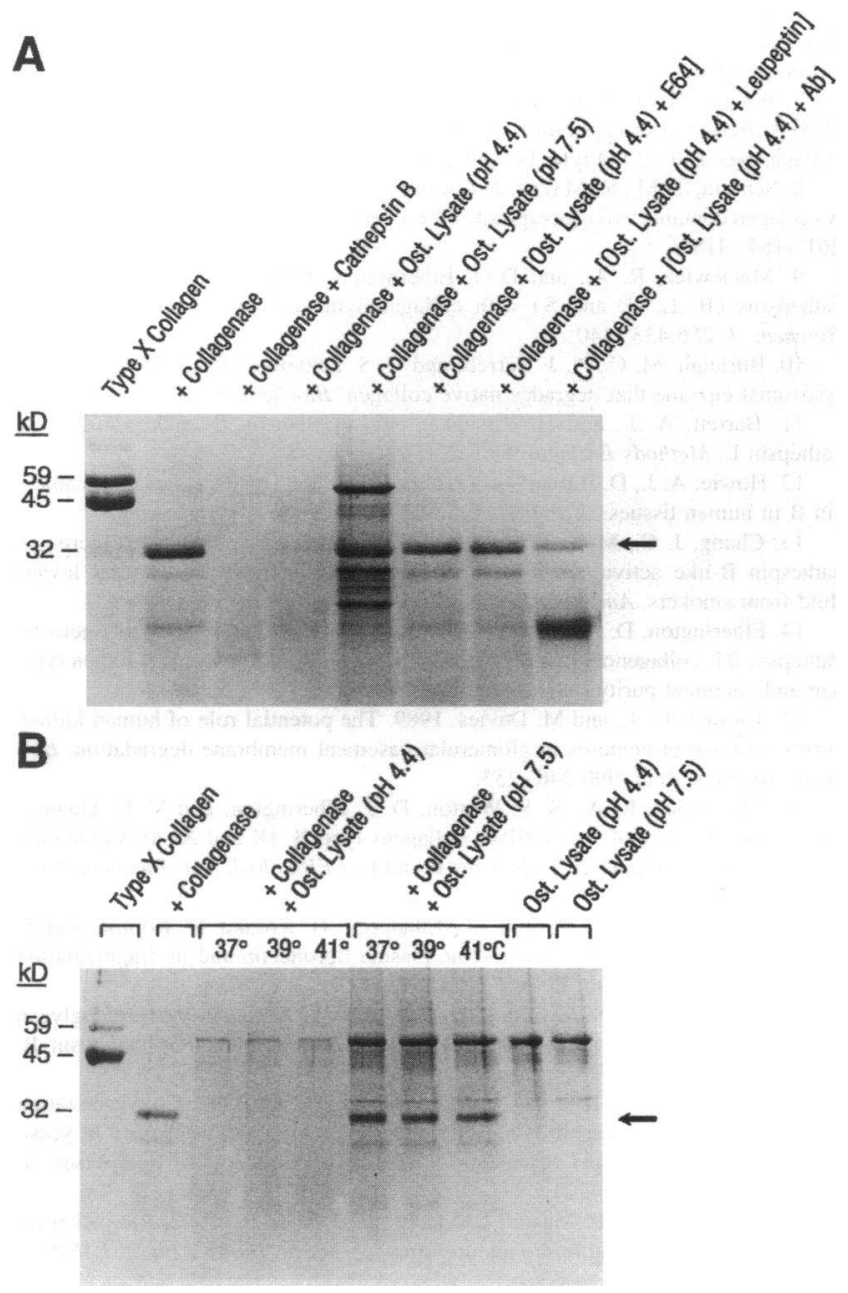

Figure 5. Degradation of the 32-kD fragment of type $\mathrm{X}$ collagen by osteoclast lysates. In $A$, type X collagen (mixture of $59,45 \mathrm{kD} ; 10 \mu \mathrm{g}$ ) was incubated at $37^{\circ} \mathrm{C}$ with collagenase $\left(1.1 \times 10^{-7} \mathrm{M}\right)$ for $18 \mathrm{~h}$ to form the stable $32-\mathrm{kD}$ product (arrow). Samples were then incubated as shown: with cathepsin B $\left(1.3 \times 10^{-7} \mathrm{M}\right)$ (lane 3); with $25 \mu \mathrm{l}$ of osteoclast lysate at $\mathrm{pH} 4.4$ for $24 \mathrm{~h}$ (lane 4 ); with $25 \mu \mathrm{l}$ of osteoclast lysate at $\mathrm{pH} 7.5$ for $24 \mathrm{~h}$ (lane 5); and with $25 \mu \mathrm{l}$ of osteoclast lysate at $\mathrm{pH} 4.4$ for $24 \mathrm{~h}$ that contained either E-64 $\left(10^{-5} \mathrm{M}\right)$ (lane 6$)$; leupeptin $\left(10^{-5} \mathrm{M}\right)$ (lane 7); or antibody to cathepsin B $(20 \mu \mathrm{g} / \mathrm{ml})$ (lane 8). The multiple molecular weight bands seen in the osteoclast lysate at pH 7.5 most likely represent precipitated proteins. In the lane with osteoclast lysate plus antibody, the prominent low $M_{\mathrm{r}}$ band running at $25.5 \mathrm{kD}$ represents IgG. In B, type $X$ collagen (mixture of 59,45 $\mathrm{kD} ; 10 \mu \mathrm{g}$ ) was incubated at $37^{\circ} \mathrm{C}$ with collagenase $\left(1.1 \times 10^{-7} \mathrm{M}\right)$ for $18 \mathrm{~h}$ to form the $32-\mathrm{kD}$ product (arrow). This product was then incubated with $25 \mu \mathrm{l}$ of osteoclast lysate at $\mathrm{pH} 4.4$ for $24 \mathrm{~h}$ at 37,39 , and $41^{\circ} \mathrm{C}$, and at $\mathrm{pH} 7.5$ for $24 \mathrm{~h}$ at 37,39 , and $41^{\circ} \mathrm{C}$. Osteoclast lysates alone are shown as indicated.

collagen is resorbed after new bone covers the spicules in the primary spongiosa, we reasoned that osteoclast enzymes were candidates for accomplishing this task. The osteoclast is a specialized cell which degrades mineralized bone by acidifying the enclosed space formed at its site of attachment to bone by a vacuolar proton pump in its ruffled membrane $(34,35)$. Evidence that this acidic microdomain does indeed exist comes from direct microelectrode measurements demonstrating that osteoclasts acidify the space between the cell and the substrate to which the cell is attached to $\mathrm{pH} 4.5$ (37). In this acidic milieu, it is believed that acidic cathepsins, such as cathepsin $B$, can function in the degradation of the organic, primarily type I collagenous matrix of bone. In the chick osteoclast, it has recently been demonstrated that cathepsin B is the acidic cathepsin responsible for this type I collagenolytic action (38).

Cathepsin B acts differently from metalloproteinases in that it cleaves collagens by first attacking the telopeptide region where intermolecular cross-links are formed, solubilizing the molecules, and then degrades the collagen into small peptide fragments (10). The actual degradation of the collagen helix is known to require both an acidic environment and physiologic temperature, implying that a requisite for attack is a subtly compromised or "lax" helical structure. In this study, we found that soluble type I collagen molecules were indeed very susceptible to cathepsin $\mathrm{B}$ degradation at $37^{\circ} \mathrm{C}, \mathrm{pH} \mathrm{4.4}$, but not at $35^{\circ} \mathrm{C}$ (Fig. 4 ). In contrast, whole type $\mathrm{X}$ collagen largely resisted attack by cathepsin $\mathrm{B}$ at $37^{\circ} \mathrm{C}$, became $\sim 50 \%$ susceptible at $39^{\circ} \mathrm{C}$, and were fully cleaved only at $41^{\circ} \mathrm{C}$. In all likelihood, these data are explained by the known differences in $T_{\mathrm{m}}$ between the two collagen types, which reflect very different hydroxyproline contents. The $T_{m}$ of type I collagen under acidic conditions is $39^{\circ} \mathrm{C}$, which is about $3^{\circ} \mathrm{C}$ lower than the $T_{\mathrm{m}}$ value measured at a neutral $\mathrm{pH}$ (39). Intact type $\mathrm{X}$ collagen, however, has a much higher $T_{\mathrm{m}}$ of $47^{\circ} \mathrm{C}$ at neutral $\mathrm{pH}(40)$. Importantly, the 32-kD type $X$ collagen fragment of interstitial collagenase digestion has a $T_{\mathrm{m}}$ of $43^{\circ} \mathrm{C}(8)$, and this fragment is fully susceptible to cathepsin $\mathrm{B}$ at $37^{\circ} \mathrm{C}$ (Fig. 4). Thus, our data suggest that at physiologic temperature, cathepsin $B$ cannot attack whole type $\mathrm{X}$ collagen, and that processing by interstitial collagenase to the $32-\mathrm{kD}$ form is required for susceptibility to the acidic cathepsin.

To test the validity of our hypothesis that complete degradation of native type $X$ collagen requires the concerted action of both a metalloproteinase and an acidic cathepsin, we tested the capacity of osteoclast lysates to degrade the 32-kD fragment of collagenase digestion. As described in Fig. 5, type $X$ collagen was first digested at neutral $\mathrm{pH}$ to a stable $32-\mathrm{kD}$ product. After this digestion was complete, the $\mathrm{pH}$ of the reaction mixture was lowered to 4.4 and osteoclast lysate added. The osteoclast lysate readily degraded the $32-\mathrm{kD}$ type $\mathrm{X}$ collagen fragment at $\mathrm{pH} 4.4$ $\left(37^{\circ} \mathrm{C}\right)$, but no degradation was observed at $\mathrm{pH} 7.5$, even at $41^{\circ} \mathrm{C}$. Degradation at acidic $\mathrm{pH}$ was completely blocked by two cysteine proteinase inhibitors-E64 and leupeptin-demonstrating that cleavage was accomplished by an acidic cysteine proteinase. Osteoclasts contain two major acidic cathepsinscathepsins $\mathrm{B}$ and $\mathrm{L}-$ which are capable of cleaving native helical collagens at acidic $\mathrm{pH}$ and physiologic temperature (34, 35 ). Antibody is available to one of these cathepsins, cathepsin $\mathrm{B}$, and we demonstrated that the capacity of whole osteoclast lysates to degrade the $32-\mathrm{kD}$ fragment of type $\mathrm{X}$ collagen was significantly inhibited in the presence of this specific antiserum. Taken as a whole, these data strongly suggest that cleavage of type $X$ collagen is initiated by interstitial collagenase, but can be completed by osteoclast-derived cathepsin B.

It must be recognized that our studies were done on chick, not human, type $\mathrm{X}$ collagen as type $\mathrm{X}$ is an embryonic collagen. The chick embryo has been variously reported to exhibit a core temperature within the range of $35-39^{\circ} \mathrm{C}(41,42)$. In this regard, we tested the various matrix metalloproteinases against the $32-\mathrm{kD}$ fragment of collagenase digestion, and even at $39^{\circ} \mathrm{C}$, no matrix metalloproteinase including $92-\mathrm{kD}$ gelatinase pro- 
duced substantial cleavage (data not shown). Furthermore, we tested osteoclast lysates at 39 and $41{ }^{\circ} \mathrm{C}$ at neutral pH (Fig. 5). Even at these higher temperatures, such lysates degraded the $32-\mathrm{kD}$ fragment only at acidic $\mathrm{pH}$ and not at neutral $\mathrm{pH}$. These data lend further support to our hypothesis that the metalloproteinases alone are not capable of fully degrading type $\mathrm{X}$ collagen and that, additionally, an osteoclast-derived acidic cysteine protease is required for complete degradation.

However, this scenario may not be the only mechanism for type $\mathrm{X}$ collagen degradation. A crude mixture of proteinases synthesized by interleukin-1 - stimulated human articular chondrocytes is able to completely degrade type $\mathrm{X}$ collagen in $16 \mathrm{~h}$ at $\mathrm{pH} 8.0,35^{\circ} \mathrm{C}(30)$. Also, some of the loss of type $\mathrm{X}$ collagen during avian long bone development occurs before hypertrophic cartilage is calcified. In this case, the cartilage is replaced by marrow, not bone, and the resorption process appears to be controlled by fibroblastic or macrophage-like cells rather than osteoclasts (43).

Based on our data, we propose the following scenario for the degradation of type $\mathrm{X}$ collagen during endochondral bone formation. During the resorption of calcified cartilage and its replacement with mineralized bone, cartilage-derived cells such as chondrocytes are able to initiate the cleavage of type $X$ collagen by the secretion of neutral metalloproteinases, such as interstitial collagenase, which degrade the substrate to a stable $32-\mathrm{kD}$ form that retains its triple helical structure. This $32-\mathrm{kD}$ fragment may have biological functions such as the chemoattraction of incoming bone cells. With the invasion of bone and replacement of cartilage, osteoclasts then complete the degradation of this $32-\mathrm{kD}$ fragment by the action of acidic cathepsins such as cathepsin B. While type $X$ collagen is a transiently and developmentally regulated matrix molecule, its importance to endochondral ossification is prominent and the consequences of its turnover to bone development and maturation may be profound.

\section{Acknowledgments}

We wish to thank Dr. Gillian Murphy (Strangeways Research Laboratory, Cambridge, England) for her kind gift of the matrilysin used in this study, Dr. John Mort (Shriner's Hospital, Montreal, Canada) for purified recombinant rat cathepsin B, and Professor Michel van der Rest (Ecolé Superior de Lyon, France) for advice and helpful discussions.

This work was supported by United States Public Health Service grants AR-32087, AR-39239, AR-35805, DK-38848, DK-45181, and DK-09976 from the National Institutes of Health, and by the Edward Mallinckrodt Department of Pediatrics. Support was also derived from grant 3524 from the Council for Tobacco Research.

\section{References}

1. Schmid, T. M., and H. E. Conrad. 1982. A unique molecular weight collagen secreted by cultured chick embryo chondrocytes. J. Biol. Chem. 257:1244412450.

2. Gibson, G. J., S. L. Schor, and M. E. Grant. 1982. Effect of matrix macromolecules on chondrocyte gene expression: synthesis of a low molecular weight collagen species by cells cultured within collagen gels. J. Cell Biol. 93:767-774.

3. Gibson, G. J., B. W. Beaumont, and M. H. Flint. 1984. Synthesis of a low molecular weight collagen by chondrocytes from the presumptive calicification region of the embryonic chick sterna: the influence of culture with collagen gels. J. Cell Biol. 99:208-216.

4. Grant, W. T., G.-J. Wang, and G. Balian. 1987. Type X collagen synthesis during endochondrial ossification in fracture repair. J. Biol. Chem. 262:98449849.

5. Schmid, T. M., and T. F. Linsenmeyer. 1983. A short chain (pro)collagen from aged endochondrial chondrocytes. J. Biol. Chem. 258:9504-9509.
6. Kwan, A. P. L., C. H. J. Sear, and M. E. Grant. 1986. Identification of disulfide bonded type $X$ procollagen polypeptides in embryonic chick chondrocyte culture. FEBS (Fed. Eur. Biochem. Soc.) Lett. 4068:267-272.

7. Welgus, H. G., C. J. Fliszar, J. L. Seltzer, T. M. Schmid, and J. J. Jeffrey. 1990. Differential susceptibility of type $X$ collagen to cleavage by two mammalian collagenases and $72 \mathrm{kD}$ type IV collagenase. J. Biol. Chem. 265:13521-13527.

8. Schmid, T. M., R. Mayne, J. J. Jeffrey, and T. F. Linsenmeyer. 1986. Type $\mathrm{X}$ collagen contains two cleavage sites for a vertebrate collagenase. J. Biol. Chem. 261:4184-4189.

9. Maciewicz, R. A., and D. J. Etherington. 1988. A comparison of four cathepsins (B, L, N, and S) with collagenolytic activity from rabbit spleen. Biochem. J. 256:433-440.

10. Burleigh, M. C., A. J. Barrett, and G. S. Lazarus. 1974. Cathepsin B1. A lysosomal enzyme that degrades native collagen. Biochem. J. 137:387-398.

11. Barrett, A. J., and H. Kirschke. 1981. Cathepsin B, cathepsin H, and cathepsin L. Methods Enzymol. 80:535-561.

12. Howie, A. J., D. Burnett, and J. Crocher. 1985. The distribution of cathepsin B in human tissues. J. Pathol. 145:307-314.

13. Chang, J. C., M. Lesser, O. H. Yoo, and M. Orlowski. 1986. Increased cathespin B-like activity in alveolar macrophages and bronchoalveolar lavage fluid from smokers. Am. Rev. Respir. Dis. 134:538-541.

14. Etherington, D. J. 1977. The dissolution of insoluble bovine collagens by cathepsin B1, collagenolytic cathepsin and pepsin. The influence of collagen type, age and chemical purity on susceptibility. Conn. Tiss. Res. 5:135-145.

15. Thomas, G. J., and M. Davies. 1989. The potential role of human kidney cortex cysteine proteinases in glomerular basement membrane degradation. Biochem. Biophys. Acta. 990:246-253.

16. Maciewicz, R. A., S. F. Wotton, D. J. Etherington, and V. C. Duance. 1990. Susceptibility of the cartilage collagens type II, IX and XI to degradation by the cysteine proteinases, cathepsins B and L. FEBS (Fed. Eur. Biochem. Soc.) Lett. 269:189-193.

17. Isemura, M., Z. Yosizawa, K. Takahashi, H. Kosaka, N. Kojima, and T. Ono. 1981. Characterization of porcine plasma fibronectin and its fragmentation by porcine liver cathepsin B. J. Biochem. 90:1-9.

18. Nguyen, Q., J. S. Mort, and P. J. Roughly. 1990. Cartilage proteoglycan aggregate is degraded more extensively by cathepsin $L$ than by cathepsin $B$. Biochem. J. 266:569-573.

19. Hasnain, S., T. Hirama, A. Tam, and J. S. Mort. 1992. Characterization of recombinant rat cathespin $\mathrm{B}$ and nonglycosylated mutants expressed in yeast. New insights into the $\mathrm{pH}$ dependence of cathespin-B-catalyzed hydrolyses. $J$. Biol. Chem. 267:4713-4721.

20. Rowan, A. D., P. Mason, L. Mach, and J. S. Mort. 1992. Rat cathepsin B. Proteolytic processing to the mature form in vitro. J. Biol. Chem. 267:1599315999.

21. Stricklin, G. P., E. A. Bauer, J. J. Jeffrey, and A. Z. Eisen. 1977. Human skin collagenase: isolation of precursor and active forms from both fibroblast and organ cultures. Biochemistry. 16:1607-1615.

22. Welgus, H. G., N. L. Connolly, and R. M. Senior. 1986. 12-0-tetradecanoyl-phorbol-13-acetate-differentiated U937 cells express a macrophage-like profile of neutral proteinases: high levels of secreted collagenase and collagenase inhibitor accompany low levels of intracellular elastase and cathepsin G. J. Clin. Invest. 77:1675-1681.

23. Wilhelm, S. M., I. E. Collier, B. L. Marmer, A. Z. Eisen, G. A. Grant, and G. I. Goldberg. 1989. SV40-transformed human lung fibroblasts secrete a 92$\mathrm{kDa}$ type IV collagenase which is identical to that secreted by normal human macrophages. J. Biol. Chem. 264:17213-17221.

24. Murphy, G., M. I. Cockett, R. V. Ward, and A. J. P. Docherty. 1991. Matrix metalloproteinase degradation of elastin, type IV collagen and proteoglycan. A quantitative comparison of the activities of $95 \mathrm{kDa}$ and $75 \mathrm{kDa}$ gelatinases, stromelysins- 1 and -2 and punctuated metalloproteinase (PUMP). Biochem. J. 277:277-279.

25. Senior, R. M., G. L. Griffin, C. J. Fliszar, S. D. Shapiro, G. I. Goldberg, and H. G. Welgus. 1991. Human 92-kilodalton and 72-kilodalton type IV collagenases are elastases. J. Biol. Chem. 266:7870-7875.

26. Welgus, H. G., J. J. Jeffrey, and A. Z. Eisen. 1981. The collagen substrate specificity of human skin fibroblast collagenase. J. Biol. Chem. 256:9511-9515.

27. Nagase, H., and J. F. Woessner. 1980. An improved assay for proteases and polysaccharidases employing a cartilage proteoglycan substrate entrapped in polyacrylamide particles. Anal. Biochem. 107:385-392.

28. Schmid, T. M., and T. F. Linsenmeyer. 1985. Immunohistochemical localization of short chain cartilage collagen (type X) in avian tissues. J. Cell Biol. 100:598-605.

29. Schmid, T. M., and T. F. Linsenmeyer. 1987. Type X collagen. In Structure and Function of Collagen Types. R. Mayne, and R. E. Burgeson, editors. Academic Press, New York. 223-259.

30. Gadher, S. J., D. R. Eyre, S. F. Wotton, T. M. Schmid, and D. E. Woodley. 1990. Cleavage of collagen type X by human synovial collagenase and neutrophil elastase. Matrix. 10:154-160.

31. Laemmli, U. K. 1970. Cleavage of structural proteins during assembly of the head of bacteriophage T4. Nature (Lond.). 277:680-685. 
32. Suda, T., N. Takahashi, and T. J. Martin. 1992. Modulation of osteoclast differentiation. Endocrine Rev. 13:66-80.

33. Buck, M. R., D. G. Karustis, N. A. Day, K. V. Honn, and B. F. Sloane. 1992. Degradation of extracellular-matrix proteins by human cathepsin B from normal and tumour tissues. Biochem. J. 282:273-278.

34. Delaisse, J.-M., Y. Eeckhout, and G. Vaes. 1984. In vivo and in vitro evidence for the involvement of cysteine-proteinases in bone resorption. Biochem. Biophys. Res. Commun. 125:441-447.

35. Delaisse, J.-M., and G. Vaes. 1992. Reactive oxygen species as potential mediators of osteoclast action. In Biology and Physiology of the Osteoclast. B. R. Rifkin, and C. V. Gay, editors. Academic Press, New York. 290-314.

36. Chan, S. J., B. San Segundo, M. B. McCormick, and D. F. Steiner. 1986. Nucleotide and predicted amino acid sequences of cloned human and mouse preprocathepsin B cDNAs. Proc. Natl. Acad. Sci. USA. 83:7721-7725.

37. Silver, I. A., R. J. Murrills, and D. J. Etherington. 1988. Microelectrode studies on the acid microenvironment beneath adherent macrophages and osteoclasts. Exp. Cell Res. 175:266-276.

38. Blair, H. C., S. L. Teitelbaum, L. E. Grosso, D. L. Lacey, H. L. Tan,
D. W. McCourt, and J. J. Jeffrey. 1993. Extracellular-matrix degradation at acid $\mathrm{pH}$. Avian osteoclast acid collagenase isolation and characterization. Biochem. J. 290:873-884

39. Hayashi, T., S. Curran-Patel, and D. J. Prockop. 1979. Thermal stability of the triple helix of type I procollagen and collagen. Precautions for minimizing ultraviolet damage to proteins during circular dichroism studies. Biochemistry. 18:4182-4187.

40. Schmid, T. M., and T. F. Linsenmeyer. 1984. Denaturation-renaturation properties of two molecular forms of short chain collagen. Biochemistry. 23:553558.

41. Whitlon, G. C. 1986. Regulation of body temperature. In Avian Physiology. P. D. Sturkie, editor. Springer-Verlag, New York. 221-252.

42. Romanoff, A. L. 1960. The effect of temperature. In The avian embryo, structural and functional development. The Macmillan Company, New York. 196-197.

43. Sorrell, J. M., and L. Weiss. 1982. The cellular organization of fibroblastic cells and macrophages at regions of uncalcified cartilage resorption in the embryonic chick femur as revealed by alkaline and acid phosphatase histochemistry. Anat. Rec. 202:491-499. 